\title{
Oxidation of Fatty Acids Are Associated with Russian Wheat Aphid Resistance in Wheat
}

\author{
J.M. BERNER ${ }^{1 *}$ and A.J. VAN DER WESTHUIZEN ${ }^{2}$ \\ ${ }^{1}$ Research Unit for Environmental Sciences and Management, North-West University, Potchefstroom, \\ Private Bag X6001, Potchefstroom, 2520, South Africa \\ ${ }^{2}$ Department of Plant Sciences, University of the Free State, Bloemfontein, \\ P.O. Box 339, Bloemfontein, 9300, South Africa \\ (Received 18 June 2012; Accepted 20 May 2014; \\ Communicated by A. Goyal)
}

\begin{abstract}
The oxidation of fatty acids, which is responsible for changes in lipid composition, were investigated in a comparative study using the Russian wheat aphid (RWA) (Diuraphis noxia), infested and un-infested resistant (Tugela DN) and close isogenic-susceptible (Tugela) wheat cultivars. LOX, which catalyzes the first step of the lipoxygenase pathway, was selectively induced in the infested resistant wheat. A pathogen-induced oxygenase protein was also found to be induced during the wheat-RWA interaction. The involvement of oxylipins in the RWA resistance response was confirmed by inhibition studies using indomethacin, which is known to inhibit prostanoid biosynthesis in mammalian tissue. Downstream defense reactions, e.g. LOX and POD activities, were inhibited upon indomethacin treatment. These results emphasize the importance of fatty acid oxidation as an essential process for the establishment of a successful defense response in wheat to the RWA.
\end{abstract}

Keywords: Diuraphis noxia, lipoxygenase, oxylipins, pathogen-induced oxygenase, Russian wheat aphid, wheat

\section{Introduction}

The Russian wheat aphid (RWA), Diuraphis noxia (Kurdjumov), is a severe global pest of small grains, especially of wheat (Triticum aestivum L., Poaceae) and barley (Hordeum vulgare L., Poaceae). Several RWA resistance genes ( $D n$ ) have been identified and are being used for the development of resistant cultivars (Du Toit 1989; Quick et al. 1996; Prinsloo 2000). Despite the efforts of developing these resistant cultivars, chemicals are still being used and the concern that a resistance-breaking biotype may develop became a reality. A new RWA biotype (designated as "biotype 2"), which is able to overcome the current resistance mechanism of wheat, was identified in the USA in 2003 (Haley et al. 2004) and in 2005 in South Africa (Tolmay et al. 2007). This new biotype proves to be more virulent and poses a great threat for wheat-producing areas.

* Corresponding author; E-mail: jacques.berner@nwu.ac.za 
Fatty acid derivatives are integral components of direct and indirect defense responses. Jasmonates, for example, are fatty acid-derived signals that activate the defense mechanism of plants against insect attack (Wasternack 2007). In addition, there are keto, hydroxyl and hydroxyperoxy fatty acids that are involved in cell death and the expression of stress-related genes (Weber 2002). The addition of molecular oxygen to polyunsaturated fatty acids leads to the formation of a large class of oxygenated fatty acids, collectively known as oxylipins (Tsitsigiannis and Keller 2007). Oxylipins play a pivotal role during defense responses. These responses include the activation of defense-related genes, antimicrobial effects, building blocks for physical barriers and hypersensitive cell death (Blée 2002; Shah 2005).

Mammalian oxylipins are derived from the arachidonic acid (C20 fatty acid) cascade that plays an important role during inflammation and infection (Nicolaou et al. 1991). Tissue exposed to various physiological and pathological stimuli produces arachidonic acid from membrane phospholipids by the action of phospholipases. The arachidonic acid is further metabolized to various oxylipins by P-450 epoxygenases, cyclooxygenase (COX) and lipoxygenase (LOX) (Harizi et al. 2008). Cyclooxygenase, for example, catalyzes the conversion of fatty acids to prostanoids resulting in a wide variety of effects such as fever, inflammation and pain (Narumiya and Furuyashiki 2011). Fever, inflammation, pain and beyond: prostanoid receptor research during these 25 years. Indomethacin is a nonselective inhibitor of COX and is used in the medical industry to inhibit prostanoid biosynthesis, thereby reducing the effects caused by prostanoids (Hofer et al. 2012).

In plants, oxylipins are derived from $\mathrm{C} 18$ fatty acids like linolenic or linoleic acid via the lipoxygenase pathway (Gardner 1991; Vick 1993). Lipoxygenase (LOX) catalyzes the addition of molecular oxygen to fatty acids containing a cis, cis,-1,4-pentadiene system to give an unsaturated fatty acid hydroperoxide (Hamberg and Samuelson 1967). LOX also catalyzes the conversion of hydroperoxy fatty acids (Kuhn et al. 1990) and synthesizes epoxy leukotrines (Shimizu et al. 1984).

The oxidation of fatty acids is implicated in plant development and is a key response to various environmental stimuli. In this paper we demonstrate that fatty acid oxidation is a key response of the defense mechanism of wheat against the Russian wheat aphid.

\section{Materials and Methods}

\section{Plant material}

Wheat plants (Triticum aestivum L.) resistant to the RWA [Diuraphis noxia (Kurdjumov)] cv. Tugela DN (PI137739/5; Du Toit 1989), and near isogenic susceptible, Tugela, were grown under controlled conditions in a glasshouse with day and night temperatures of $25^{\circ} \mathrm{C}$ and $20^{\circ} \mathrm{C}$, respectively. Tugela DN contains the DN1 resistance genes, which were introduced into Tugela through a backcross breeding program. Plants were infested on the second leaf growth stage by spreading the aphids over the plants, approximately 25 aphids per plant. 
Plant material was collected after 3, 6, 9, 12, 48, 96 and 120 hours after the onset of infestation. The entire plant was cut off $1 \mathrm{~cm}$ from the surface of the soil, the aphids removed and the plant material were immediately frozen in liquid nitrogen and stored at $-20^{\circ} \mathrm{C}$ for subsequent analyses.

\section{Determination of lipid peroxidation}

Lipid peroxidation was determined by measuring malondialdehyde (MDA). Plant tissue was homogenised with the aid of inert sand in $2.5 \mathrm{~mL}$ (per $1 \mathrm{~g}$ fresh mass) of ice-cold $0.1 \%$ $(\mathrm{m} / \mathrm{v})$ trichloroacetic acid (TCA), 1\% (v/v) Triton X-100 and $0.01 \%(\mathrm{v} / \mathrm{v})$ butylhydroxytoluene (BHT). Triton X-100 destroys the membranes and the BHT is a synthetic antioxidant. After centrifugation (5 min, $1000 \mathrm{~g}), 4 \mathrm{~mL}$ of $20 \%(\mathrm{~m} / \mathrm{v})$ TCA containing $0.5 \%(\mathrm{v} / \mathrm{v})$ TBA (2-thiobarbituric acid) was added to $1 \mathrm{~mL}$ aliquot of the supernatant. The mixture was heated at $95^{\circ} \mathrm{C}$ for $20 \mathrm{~min}$ then cooled down on ice and centrifuged for $5 \mathrm{~min}$ at $1000 \mathrm{~g}$. The absorbance of the supernatant was measured at 532, subtracting the value for non-specific absorption at $600 \mathrm{~nm}$ (Heath and Parker 1968).

\section{Extraction procedure of enzymes}

The extraction of enzymes was performed according to Rao et al. (1997). One gram of frozen leaf tissue was ground in $10 \mathrm{~mL}$ of $100 \mathrm{mM}$ potassium phosphate buffer $(\mathrm{pH} 7.5)$ containing $100 \mathrm{mg}$ acid-washed sand, $1 \mathrm{mM}$ ethylenediaminetetra-acetic acid (EDTA) and $1 \%(\mathrm{~m} / \mathrm{v})$ polyvinylpyrrolidone (PVP). After centrifugation (25 $000 \mathrm{~g}, 20 \mathrm{~min})$, the supernatant was used for LOX and peroxidase (POD) assays.

\section{Determination of protein concentration}

The protein concentration was determined using a Biorad Microplate Reader model 3550 at $595 \mathrm{~nm}$ (Rybutt and Parish 1982). A dye-binding assay technique was used (Bradford 1976). The assay mixture consisted of $150 \mu \mathrm{L}$ distilled water, $40 \mu \mathrm{L}$ BioRAD and $10 \mu \mathrm{L}$ enzyme extract and for the protein standard, $10 \mu \mathrm{L}$ of a $0.5 \mu \mathrm{g} \cdot \mu \mathrm{L}^{-1} \gamma$-globulin solution was used.

\section{Lipoxygenase (LOX, EC 1.13.11.12) assay}

The assay was done according to the methods of Grossmann and Zakut (1979) and Ocampo et al. (1986). The LOX reaction mixture consisted of $1 \mathrm{~mL} 0.1 \mathrm{M}$ sodium citrate phosphate buffer ( $\mathrm{pH} 6.2$ ), $50 \mu \mathrm{L}$ of enzyme extract and $150 \mu \mathrm{L}$ of $2.5 \mathrm{mM}$ linoleic acid. The change in absorbance was measured at $234 \mathrm{~nm}$ for $15 \mathrm{~min}$ at $30^{\circ} \mathrm{C}$ with a double beam spectrophotometer equipped with a temperature-controlled water bath. LOX was expressed as nmol HPOD. $\mathrm{mg}^{-1}$ protein. $\mathrm{min}^{-1}$.

Preparation of the linoleic acid substrate (2.5 mM linoleic acid in 0.15\% Tween 20)

Linoleic acid $(400 \mu \mathrm{L}), 768 \mu \mathrm{L}$ Tween 20 and $40 \mathrm{~mL}$ methanol were added in a round-bottomed flask and subjected to rotary evaporation under reduced pressure at $60^{\circ} \mathrm{C}$ until dry. The residue was re-dissolved in $500 \mathrm{~mL} 0.05 \mathrm{M}$ sodium phosphate buffer ( $\mathrm{pH}$ 9). The en- 
tire volume was divided into $5 \mathrm{~mL}$ aliquots and stored in airtight bottles at $-20^{\circ} \mathrm{C}$. During transfer to the air-tight bottles, nitrogen gas was bubbled through the content of the round-bottomed flask and into the small bottles before adding the aliquots. The substrate was used once and stored on ice during experiments.

\section{Indomethacin inhibition}

Indomethacin is an inhibitor of prostanoid biosynthesis (Hofer et al. 2012). After 72 hours of infestation, plants were cut off just above the ground and placed in a solution of 20 $\mu \mathrm{g} \cdot \mathrm{mL}^{-1}$ indomethacin. Excised plants were left in the solution $(50 \mathrm{~mL})$ for two hours, transferred to a beaker containing pure water $(50 \mathrm{~mL})$, and left for another two hours, where after LOX and peroxidase (POD) activities were determined. In addition, indomethacin solution $40 \mu \mathrm{g} \cdot \mathrm{mL}^{-1}$ was given as a soil drench $(500 \mathrm{~mL}) 24$ hours before sampling. The in vitro effect of indomethacin inhibition on enzyme activity was investigated by adding indomethacin to the assay mixture. The final concentration of indomethacin in the LOX and POD assay mixtures was $40 \mu \mathrm{g} \cdot \mathrm{mL}^{-1}$.

\section{Peroxidase (POD, EC 1.11.1.7) assay}

Frozen leaf tissue was ground in liquid $\mathrm{N}_{2}$ and subsequently extracted in $3 \mathrm{~mL}$ extraction buffer [100 mM Na-acetate (pH 5.5), $10 \mathrm{mM}$ mercaptoethanol, $2 \mathrm{mM}$ EDTA, $2 \mathrm{mM}$ phenylmethylsulfonyl fluoride (PMSF)]. The homogenate was centrifuged (12,000 g, 20 $\min )$ at $2^{\circ} \mathrm{C}$.

The peroxidase (POD) assay mixture consisted of $40 \mathrm{mM}$ potassium phosphate buffer (pH5.5), $5 \mathrm{mM}$ guaiacol and $8.2 \mathrm{mM} \mathrm{H}_{2} \mathrm{O}_{2}$. The change in absorbance was measured at $470 \mathrm{~nm}$ for 180 seconds at $30^{\circ} \mathrm{C}$ (Hitachi U-2000 double-beam spectrophotometer) (Zieslin and Ben-Zaken 1991). POD activity is expressed as nmol tetraguaiacol.mg ${ }^{-1}$ protein. $\min ^{-1}$.

\section{SDS-Page and immunoblotting}

Sodium dodecyl sulphate polyacrylamide gel electrophoresis (SDS-PAGE) was carried out on a $10 \%(\mathrm{~m} / \mathrm{v})$ separating gel in a Mini Protein II gel system (BioRAD), according to Laemmli (1970), at $200 \mathrm{~V}$ constant voltage for $60 \mathrm{~min}$. The separating gel $(7.5 \%)$ consisted of $4.85 \mathrm{~mL} 2 \times$-distilled water, $2.5 \mathrm{~mL} 1.5 \mathrm{M}$ Tris- $\mathrm{HCl}(\mathrm{pH} 8.8), 100 \mu \mathrm{L} 10 \%$ (w/v) SDS, $3.3 \mathrm{~mL}$ (30\% stock) acrylamide:bisAcrylamide, $50 \mu \mathrm{L} \mathrm{10 \% (w/v)} \mathrm{ammonium} \mathrm{per-}$ sulphate and $5 \mu \mathrm{L}$ N,N,N',N'-tetramethylenediamine (TEMED). The stacking gel (6\%) consisted of ( $30 \% \mathrm{~m} / \mathrm{v}$ stock) acrylamide:bisAcrylamide, $0.5 \mathrm{M}$ Tris- $\mathrm{HCl}(\mathrm{pH} 8.6), 2.7$ $\mathrm{mL} 2 \times$-distilled water, $10 \%(\mathrm{w} / \mathrm{v})$ SDS and $10 \%(\mathrm{v} / \mathrm{v})$ TEMED.

Electroblotting onto a nitrocellulose membrane was performed for $45 \mathrm{~min}$ in a semi-wet transfer unit (Wet transfer unit from BioRAD) at a constant current of $350 \mathrm{~mA}$ in a transfer buffer ( $25 \mathrm{mM}$ Tris, $192 \mathrm{mM}$ glycine and 20\% (v/v) methanol, pH 8.3). Afterwards, the nitrocellulose membranes (Hybond-C, extra membrane, Amersham Biosciences) were blocked by incubating them in $8 \%(\mathrm{~m} / \mathrm{v})$ skim milk in TBS at room temperature for $45 \mathrm{~min}$. Incubation with anti-bean LOX (gift from Ivo Feussner*) and anti-to- 
bacco pathogen-induced oxygenase (PIOX, gift of Carmen Castresana*) antibodies in blocking solution (1:2000) was carried out for $1 \mathrm{~h}$ at room temperature. After $3 \times 10 \mathrm{~min}$ washes in TBST, the nitrocellulose membranes were incubated in alkaline phosphataseconjugated secondary antibodies (anti-chicken IgG, 1:9500 in 4\% (m/v) skim milk) for $1 \mathrm{~h}$ at room temperature. Consequently, the membranes were washed $3 \times$ in TBST and $0.05 \%$ $(\mathrm{w} / \mathrm{v})$ SDS, $2 \times$ in TBST and $1 \times$ in TBS; for 5 min each. Wide-range protein molecular mass markers (7200-206000 Da) from BioRad were used to estimate the molecular masses of detected proteins on blots and gels.

\section{Statistical analysis}

Six plants of each treatment were collected. Enzyme activities were repeated four times for each sample. Statistical analyses were performed using STATISTICA, version 12, from StatSoft ${ }^{\circledR}$. The normality of the data was checked using the Shapiro-Wilkes test. A one-way ANOVA, using the Tukey HSD test ( $95 \%$ level of significance), was used to test for significant differences between treatments. The purpose of the ANOVA was to check whether there is a statistical difference in the enzyme activities between the infested resistant wheat and the corresponding controls.

\section{Results}

\section{The effect of RWA infestation on lipid peroxidation}

A significant increase $(P<0.05)$ in lipid peroxidation was observed in the infested resistant wheat (Fig. 1) after 12 hours after infestation and onwards to 96 hours after infestation. No significant changes was observed between the infested susceptible, the un-infested susceptible and the un-infested resistant wheat plants during the course of infestation. However, after 96 hours of infestation, the level of lipid peroxidation in the un-infested resistant plants was significantly higher compared to the infested susceptible and the un-infested susceptible plants. The level of lipid peroxidation was $120 \%$ higher in the infested resistant ( $33 \mu \mathrm{mol}$ MDA. $\mathrm{min}^{-1} \cdot \mathrm{g}^{-1}$ fresh mass) wheat compared to the un-infested resistant (15 $\mu \mathrm{mol} \mathrm{MDA} \cdot \mathrm{min}^{-1} \cdot \mathrm{g}^{-1}$ fresh mass) plants. Compared to the infested $(10 \mu \mathrm{mol}$ MDA. $\min ^{-1} \cdot \mathrm{g}^{-1}$ fresh mass) and the un-infested (9 $\mu$ mol MDA.min ${ }^{-1} \cdot \mathrm{g}^{-1}$ fresh mass) susceptible plants an increase of more than $200 \%$ was observed in the infested resistant wheat.

\section{The effect of RWA infestation on LOX activity and protein expression}

As early as 6 hours after infestation, a differential increase $(P<0.05)$ in LOX activity was observed in the infested resistant wheat when compared to the corresponding controls (Fig. 2). This differential increase in LOX activity increased as infestation progressed $(P<0.05)$. During the course of infestation, there were no statistical differences between the un-infested resistant, the infested susceptible and the un-infested susceptible plants. At 120 hours after infestation, LOX activity increased to $1275 \mathrm{nmol}$ HPOD. $\mathrm{mg}^{-1}$ protein. $\mathrm{min}^{-1}$, an increase of more than a $1000 \%$ compared to the non-infested resistant wheat 


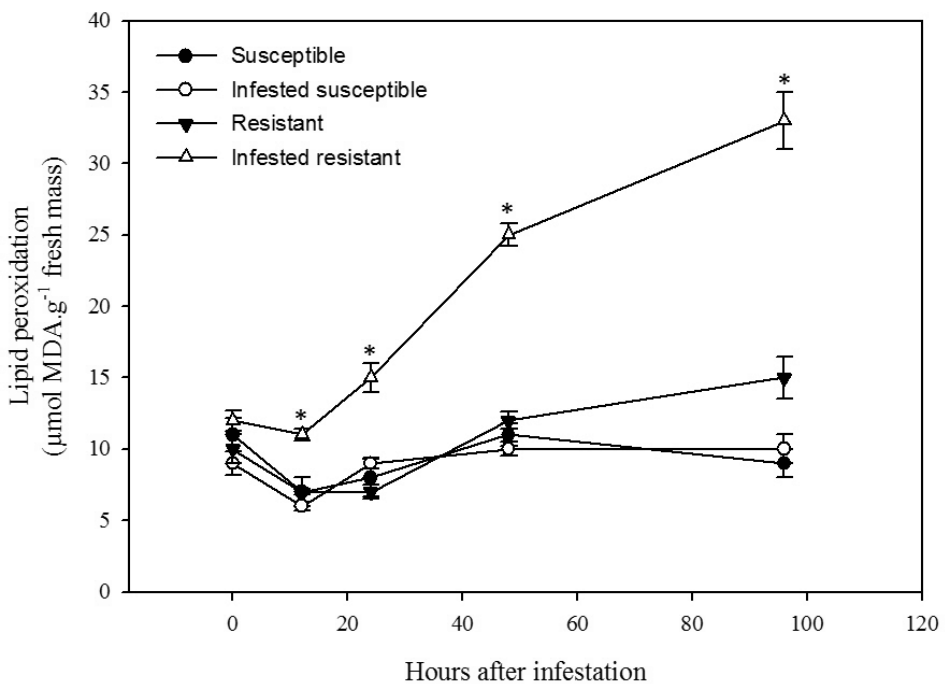

Figure 1. The effect of RWA infestation on lipid peroxidation of the susceptible Tugela and the resistant Tugela DN wheat cultivars. Error bars indicate standard error. Asterisks denote significant increases above the corresponding controls $(P<0.05)$. MDA: malondialdehyde

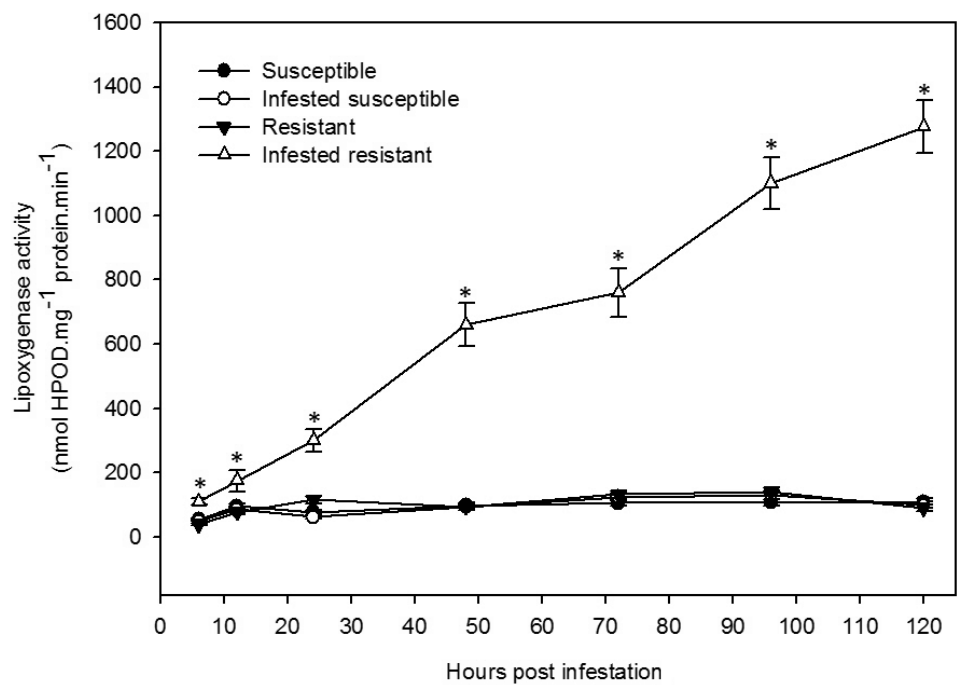

Figure 2. The effect of RWA infestation on LOX activity of the susceptible Tugela and the resistant Tugela DN wheat cultivars. Error bars indicate standard error. Asterisks denote significant increases above the corresponding controls $(P<0.05)$. HPOD: hydroperoxy octadecanoic acid

and the infested susceptible wheat, which was 90 and 102 nmol HPOD. $\mathrm{mg}^{-1}$ protein. $\mathrm{min}^{-1}$, respectively. There were no statistical differences in the expression of LOX activity between the infested susceptible (102 nmol HPOD. $\mathrm{mg}^{-1}$ protein. $\mathrm{min}^{-1}$ ) and un-in- 
fested susceptible wheat ( $90 \mathrm{nmol} \mathrm{HPOD} \cdot \mathrm{mg}^{-1}$ protein. $\mathrm{min}^{-1}$ ). The infested susceptible wheat was unable to induce LOX activity to higher as were observed in the infested resistant wheat.

A $\sim 78 \mathrm{kDa}$ LOX protein was selectively induced, to a much higher level in the resistant than in susceptible wheat during infestation (Fig. 3a). This induction started after 12 hours of infestation and increased gradually as infestation proceeded (Fig. 3b). This LOX protein was weakly expressed in the un-infested resistant and susceptible wheat cultivars, although a somewhat higher level can be observed in the un-infested resistant compared to the un-infested susceptible wheat plants (Fig. 3a). It is also clear that a slight induction occurred in the susceptible wheat after infestation. The LOX antibodies also cross-reacted with a $\sim 76 \mathrm{kDa}$ protein; especially in the susceptible cultivar. A somewhat lower expression of this protein occurred after infestation of the susceptible cultivar.
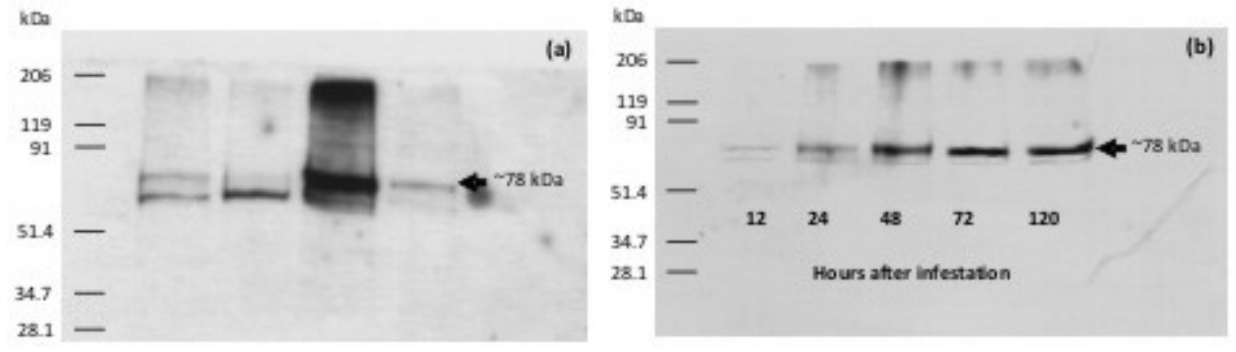

Figure 3. Western blot analyses of the effect of RWA infestation on LOX protein expression

(a) after 120 hours of infestation in the susceptible Tugela and the resistant Tugela DN wheat cultivars and

(b) in a time course of expression of LOX protein in the infested resistant Tugela DN wheat

\section{The effect of RWA infestation on the expression of a pathogen-induced oxygenase protein}

The pathogen-induced oxygenase antibodies cross-reacted with one protein in the resistant and susceptible cultivars. The $80 \mathrm{kDa}$ protein was differentially expressed in the two cultivars after infestation. Induction was much higher in the resistant than in the susceptible cultivar (Fig. 4).

\section{The effect of indomethacin inhibition on $L O X$ and POD activities}

The in vivo effects of indomethacin inhibition on the possible involvement of prostanoid-like compounds were studied in infested resistant and susceptible wheat. LOX and POD activities were determined for signs of inhibition because of possible prostanoid-like inhibition. LOX activity (Fig. 5) declined significantly $(P<0.05)$ in both the resistant and susceptible wheat plants after indomethacin treatment. A significant $(P<0.05)$ decline in POD activity (Fig. 6) was only observed in the resistant wheat after indomethacin was given as a soil drench. 


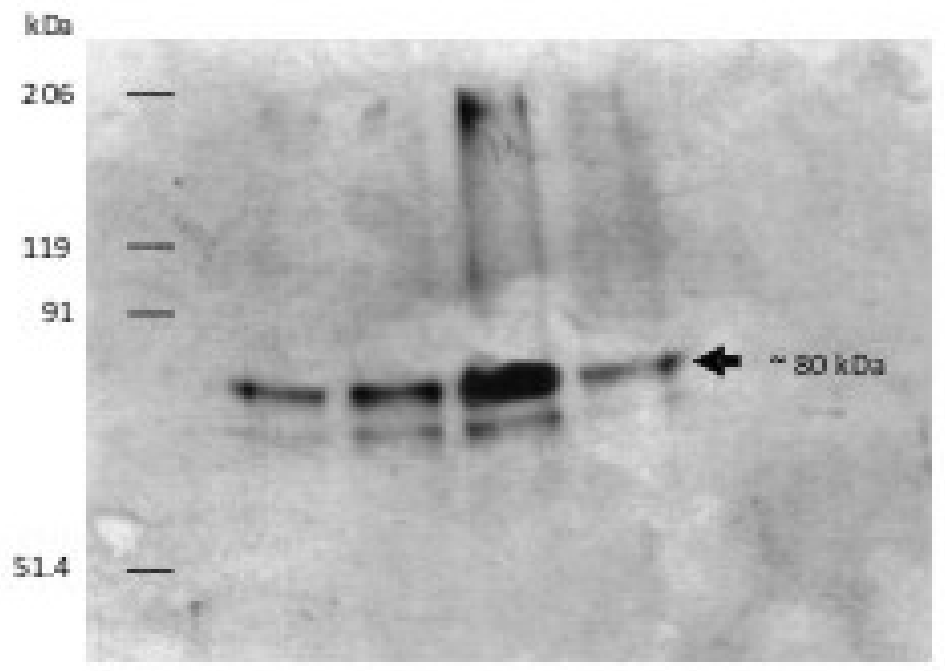

Figure 4. Western blot analyses of the effect of RWA infestation on a pathogen-induced oxygenase protein after 120 hours of infestation in the susceptible Tugela and the resistant Tugela DN wheat cultivars

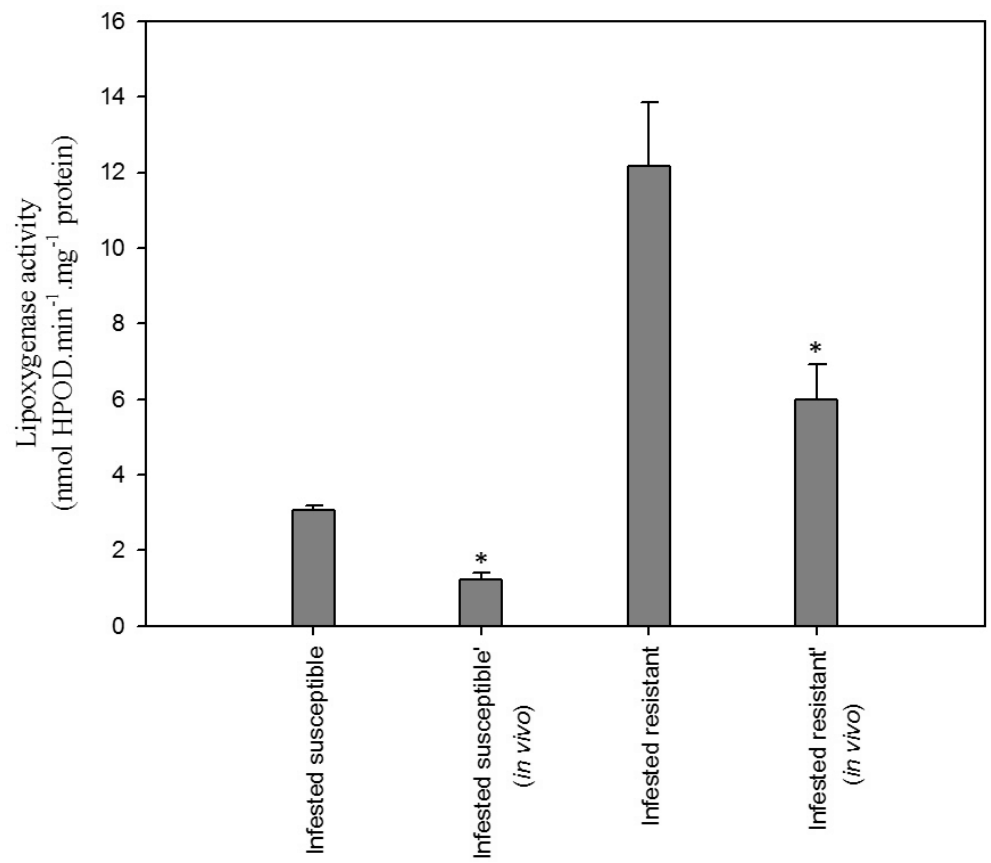

Figure 5. The in vivo (') effect of indomethacin on LOX activity in infested, susceptible and resistant wheat after infestation with the RWA. Error bars indicate standard error. Asterisks denote significant differences compared to the corresponding controls $(P<0.05)$. HPOD: hydroperoxy octadecanoic acid 


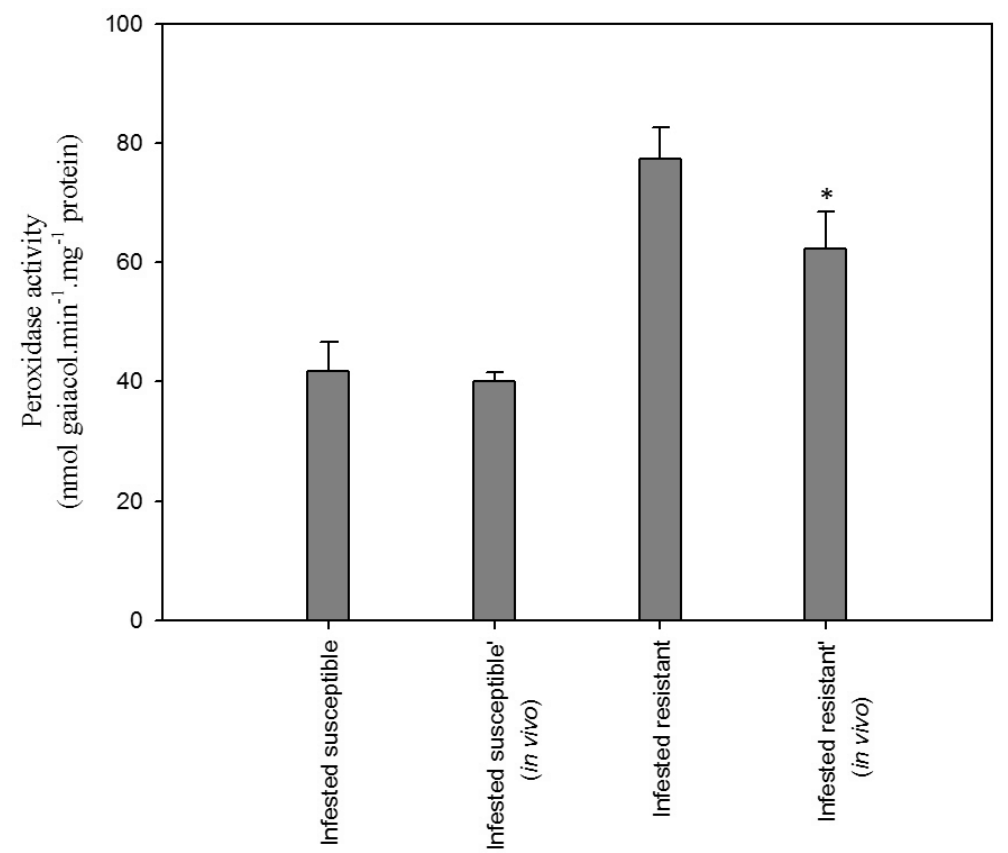

Figure 6. The in vivo (') effect of indomethacin on POD activity in infested, susceptible and resistant wheat after infestation with the RWA. Error bars indicate standard error. Asterisk denotes significant differences compared to the corresponding controls $(P<0.05)$. HPOD: hydroperoxy octadecanoic acid

\section{Discussion}

Fatty acids are important building blocks of more complex lipids, which are common in all living cells. Besides being constituents of membranes and storage lipids, fatty acids and their derivatives are important components of a plant's defense mechanism. The composition and turnover of lipids changes during the different developmental stages of a plant and in response to stress. The oxidation of unsaturated lipids, lipid peroxidation, is one of the main reactions when cells are exposed to stress and is often used as an indicator of stress (Montillet et al. 2002). Lipid peroxidation can occur either by means of chemical oxidation or by means of the action of enzymes such as LOX (Andreou et al. 2009). Peroxidation of lipids alters the physicochemical properties of membrane lipid bilayers, resulting in severe cellular dysfunction. The formation of lipid by-products as a result of lipid peroxidation can result in either beneficial and/or detrimental biological effects (Catalá 2009). The observed increase in lipid peroxidation during the incompatible interaction between wheat and the RWA (Fig. 1) is an indication of the possible involvement of oxylipins during the defense mechanism. Increases in lipid peroxidation associated with resistance have been found where plants have been treated with a fungal elicitor (Polkowska-Kowalczyk et al. 2008), where cabbage (Brassica olereacea) plants were in- 
fested with aphids (Brevicoryne brassicae L.) (Khattab 2007) and where Arabidopsis were infected with a bacteria strain (Zoeller et al. 2012).

Enzymatic lipid peroxidation occurs through the oxygenation of polyunsaturated fatty acids via a LOX-catalyzed step known as the oxylipin pathway. Products derived from the oxylipin pathway are involved in the activation of defense-related genes, antimicrobial effects, building blocks for physical barriers and hypersensitive cell death (Blée 2002; Shah 2005). LOX is a key enzyme in regulating the biosynthesis of these oxylipins where it catalyzes the oxygenation of lipids.

LOX activity is induced in several incompatible interactions in plants. Transgenic tobacco expressing antisense LOX demonstrated that an incompatible interaction could be suppressed in plant resistance to pathogens (Rancé et al. 1998). The inhibition and activation of the LOX pathway inhibits or activates cell death (Rustérucci et al. 1999). Susceptible wheat plants infested with the RWA did not increase LOX activity on infestation (Fig. 2). However, resistant wheat plants showed a differential increase in LOX activity (Fig. 2) after infestation with the RWA. This is a strong indication that the LOX pathway is involved during the incompatible interaction of wheat and the RWA. Western blot analyses confirmed the differential induction of LOX activity in the infested resistant cultivars (Fig. 3a). A $78 \mathrm{kDa}$ LOX protein was selectively induced by means of RWA infestation to greater quantities in the resistant wheat. There are numerous reports describing the differential induction of a LOX protein during incompatible biotic and abiotic stresses (Bohland et al. 1997; Rustérucci et al. 1999; Göbel et al. 2001). The $78 \mathrm{kDa}$ protein distinctively increases quantitatively as infestation proceeded (Fig. 3b). The LOX protein was only expressed after infestation, indicating that the selective induction of LOX is genetically controlled and a signal is required for its induction. Susceptible plants do not contain the resistance gene to the RWA and it is therefore evident that there is no selective expression of the LOX protein. Pea roots infested with a nematode selectively expressed a $96 \mathrm{kDa}$ LOX protein and a $78 \mathrm{kDa}$ LOX protein was also present, but not selectively induced (Leone et al. 2001). The $78 \mathrm{kDa}$ LOX protein found in wheat could be the protein responsible for increases in LOX activity when confronted with aphids or sucking insects. The type of LOX isoform induced will determine the kind of downstream LOX products being synthesised. During pathogenesis, a $92 \mathrm{kDa}$ LOX protein was formed, which is mainly responsible for the resistance response of wheat against pathogens. The LOX-92 predominantly catalyses the formation of 9-hydroperoxy fatty acids (Bohland et al. 1997). It seems therefore that the LOX pathway followed for sucking insects differs from the pathway followed for grazing insects and pathogens.

A pathogen-induced oxygenase protein was found to be induced in tobacco leaves after treatment with a pathogen elicitor. This oxygenase protein has homology to animal cyclo-oxygenase (COX) or prostaglandin endoperoxide synthase (Sanz et al. 1998). COX is a key enzyme in the production of oxylipin signal molecules that regulate diverse cellular processes in vertebrates (Ntambi 2005; Hannun and Obeid 2008). COX catalyses the conversion of polyunsaturated fatty acids, such as arachidonic acid (20:4), to prostaglandin and other eicosanoids. The oxygenase in tobacco plants has a structural core similar to that of mammalian COX. Studies on the protein functionality demonstrated that the to- 
bacco oxygenase protein possesses at least one of the two enzymatic activities of prostaglandin endoperoxide synthase (Sanz et al. 1998). These compounds regulate the immune response and inflammation reaction in response to pathogen infection in mammalian cells. Treating wheat plants with indomethacin demonstrates the possible involvement of oxylipins during the wheat-RWA interaction (Figs 5 and 6). In addition, salicylic acid, jasmonic acid, wounding and oxygen radicals can activate the oxygenase gene in plants (Sanz et al. 1998; Kim et al. 2002). Oxygenases seem therefore to play an important role in various forms of biotic stresses. The RWA also managed to induce the pathogen-induced oxygenase protein in the infested resistant wheat (Fig. 4). The inability of the susceptible wheat to express the pathogen-induced oxygenase protein to higher levels provides information for a strong argument that it contributes to the defense strategy of wheat to the RWA.

In this paper, we have demonstrated for the first time the selective induction of LOX and the involvement of a pathogen-induced oxygenase protein in the incompatible interaction between resistant wheat and the Russian wheat aphid. The selective induction of LOX and a pathogen-induced oxygenase argue for a strong possibility that oxidation of fatty acids play a pivotal role during the defense response of the resistant, Tugela DN, wheat to the RWA. Oxylipins are known to perform various roles in the plant's response to biotic and abiotic stresses, both as antimicrobial compounds and as signal molecules that lead to the activation of specific defense genes.

\section{Acknowledgements}

We wish to acknowledge the financial support of the National Research Foundation, Winter Cereal Trust and the University of the Free State towards this study. The authors would like to thank Ivo Feussner at the Department of Plant Biochemistry, Institute of Plant Bio Sciences, University of Göttingen, Germany for the anti-bean LOX antibodies and Carmen Castresana, Centro Nacional de Biotecnologia, Campus de Universidad Autonoma Cantoblanco for the anti-tobacco PIOX antibodies.

\section{References}

Andreou, A., Brodhum, F., Feussner, I. 2009. Biosynthesis of oxylipins in non-mammals. Prog. Lipid Res. 48:148-170.

Blée, M. 2002. Impact of phyto-oxylipins in plant defence. Trends Plant Sci 7:315-322.

Bohland, C., Balkenhohl, T., Loers, G., Feussner, I., Grambow, H.J. 1997. Differential induction of lipoxygenase isoforms in wheat upon treatment with rust fungus elicitor, chitin oligosaccharides, chitosan and methyl jasmonate. Plant Physiol. 114:679-685.

Bradford, M.M. 1976. A rapid and sensitive method for the quantification of micron quantities of protein utilizing the principle of protein dye binding. Anal. Biochem. 72:248-254.

Catalá, A. 2009. Lipid peroxidation of membrane phospholipids generates hydroxy-alkenals and oxidized phospholipids active in physiological and/or pathological conditions. Chem. Phys. Lipids 157:1-11.

Du Toit, F. 1989. Inheritance in two Triticum aestivum lines to Russian wheat aphid (Homo:aphididae). J. Econ. Entomol. 82:1251-1253.

Gardner, H.W. 1991. Recent investigations into the lipoxygenase pathway of plants. Biochem. Biophys. Acta 1084:221-239.

Cereal Research Communications 43, 2015 
Göbel, C., Feussner, I., Schmidt, A., Scheel, D., Sanchez-Serrano, J., Hanberg, M., Rosahl, S. 2001. Oxylipin profiling reveals the preferential stimulation of the 9-lipoxygenase pathway in elicitor-treated potato cells. J. Biol. Chem. 276:6267-6273.

Grossmann, S., Zakut, R. 1979. Determination of lipoxygenase (lipoxydase). Meth. Biochem. Anal. 25:303-329.

Haley, S.D., Peairs, F.B., Walker, C.B., Rudolph, J.B., Randolph, T.L. 2004. Occurrence of a new Russian wheat aphid biotype in Colorado. Crop Sci. 44:1589-1592.

Hamberg, M., Samuelson, B. 1967. On the specificity of the oxygenation of unsaturated fatty acids catalysed by soybean lipoxidase. J. Biol. Chem. 242:5329-5335.

Hannun, Y.A., Obeid, L.M. 2008. Principles of bioactive lipid signalling: Lessons from sphingolipids. Nature Rev. Mol. Cell. Biol. 9:139-150.

Harizi, H., Corcuff, J-B., Gualde, N. 2008. Arachidonic-acid-derived eicosanoids: Roles in biology and immunopathology. Trends Mol. Med. 14:461-469.

Heath R.L., Parker, L. 1968. Photoperoxidation in isolated chloroplasts. I. Kinetics and stoichiometry of fatty acid peroxidation. Arch. Biochem. Biophys. 125:89-198.

Hofer, M., Pospíšil, M., Hoferová, Z., Weiterová, L., Komůrková, D. 2012. Stimulatory action of cyclooxygenase inhibitors on Hematopoiesis: A review. Molecules 17:5615-5625.

Khattab, H. 2007. The defence mechanism of cabbage plant against phloem-sucking aphid (Brevicoryne brassicae L.). Aus. J. Basic and Appl. Sci. 1:56-62.

Kim, Y-C., Yi, S-Y., Mang, H.G., Seo, Y.S., Kim, WT, Choi, D. 2002. Pathogen-induced expression of cyclo-oxygenase homologue in hot pepper (Capsicum annuum cv. Pukang). J. Exp. Bot. 53:383-385.

Kuhn, H., Sprecher, H., Brash, A.R. 1990. On singular or dual positional specificity of lipoxygenases. The number of chiral products varies with alignment of methylene groups at the active site of the enzyme. J. Biol. Chem. 265:16300-16305.

Laemmli, U.K. 1970. Cleavage of structure proteins during the assembly of the head bacteriophage T4. Nature 227:680-685.

Leone, A., Melillo, M.T., Bleve-Zacheo, T. 2001. Lipoxygenase in pea roots subjected to biotic stress. Plant Sci. 161:703-717.

Montillet, J-L., Agnel, J.P., Ponchet, M., Vailleau, F., Roby, D., Triantaphylidès, C. 2002. Lipoxygenase-mediated production of fatty acid hydroperoxides is a specific signature of the hypersensitive reaction in plants. Plant Physiol. Biochem. 40:633-639.

Narumiya, S., Furuyashiki, T. 2011. Fever, inflammation, pain and beyond: Prostanoid receptor research during these 25 years. The FASEB Journal 25:813-818.

Nicolaou, K.C., Ramphal, J.Y., Petasis, N.A., Serhan, M.H. 1991. Lipoxins and related eicosanoids: Biosynthesis, biological properties, and chemical synthesis. Angew. Chem. Int. Ed. Engl. 30:1100-1116.

Ntambi, J.M. 2005. Polyunsaturated fatty acid regulation of genes of lipid metabolism. Annu. Rev. Nutr. 25:317-340.

Ocampo, C.A., Moerschbacher, B.M., Grambow, H.J. 1986. Increased lipoxygenase activity is involved in the hypersensitive response of wheat leaf cells infected with the avirulent rust fungi or treated with fungal elicitor. Z. Naturforsch. 41c:559-563.

Polkowska-Kowalczyk, L., Montilletb, J-L., Agnelb, J-P., Triantaphylides, B.C., Wielgat, B., Maciejewska, U. 2008. Changes in the initial phase of lipid peroxidation induced by elicitor from Phytophthora infestans in Solanum species. J. Plant Physiol. 165:1929-1939.

Prinsloo, G.J. 2000 Host and host instar preference of Aphelinus sp. nr. varipes (Hymenoptera: Aphelinidae) in South Africa. Afr. Entomol. 8:57-61.

Quick, J.S., Ellis, G.E., Normann, R.M., Stormberger, J.A., Shanahan, J.F., Peairs, F.B., Lorenz, K. 1996. Registration of 'Halt' wheat. Crop Sci. 36:210.

Rancé, I., Fourier, J., Esquerré-Tugayé, M-T. 1998. The incompatible interaction between Phytophthora parasitica var. nicotianae race 0 and tobacco is suppressed in transgenic plants expressing antisense lipoxygenase sequences. Proc. Natl Acad. Sci. USA 95:6554-6559.

Rao, M.V., Paliyath, G., Ormond, D.G., Murr, D.P., Watkins, C.B. 1997. Influence of salicylic acid on $\mathrm{H}_{2} \mathrm{O}_{2}$ production, oxidative stress, and $\mathrm{H}_{2} \mathrm{O}_{2}$-mediating enzymes. Plant Physiol. 115:137-149.

Rustérucci, C., Montillet, J-L., Agnel, J-P., Battesti, C., Alonso, B., Knoll, A., Bessoules, J-J., Etienne, P., Suty, L., Blein, J-P., Triantaphylides, C. 1999. Involvement of lipoxygenase-dependent production of fatty acid 
96 BERNER and VAN DER WESTHUIZEN: Changes in Lipid Biosynthesis in Resistant Wheat

hydroperoxides in the development of the hypersensitive cell death induced by cryptogein on tobacco leaves. J. Biol. Chem. 274 51:36446-36455.

Rybutt, D.B., Parish, C.R. 1982. Protein determination on an automatic spectrophotometer. Anal. Biochem. $121: 213-214$

Sanz, A., Moreno, J.I., Castresana, C. 1998. PIOX, a new pathogen-induced oxygenase with homology to animal pathogen-inducible oxygenases. The Plant Cell 10:1523-1537.

Shah, J. 2005. Lipids, lipases, and lipid-modifying enzymes in plant disease resistance. Annu. Rev. Phytopathol. 43:229-260.

Shimizu, T., Radmark, O., Samuelsson, B. 1984. Enzyme with dual lipoxygenases activities catalyses leukotriene A4 synthesis from arachidonic acid. Proc. Natl Acad. Sci. USA 81:689-693.

Tolmay, V.L., Lindeque, R.C., Prinsloo, G.J. 2007. Preliminary evidence of a resistance-breaking biotype of the Russian wheat aphid Diuraphis noxia (Kurdjumov) (Homoptera: Aphididae), in South Africa. Afr. Entomol. 15:228-230.

Tsitsigiannis, D.I., Keller, N.P. 2007 Oxylipins as developmental and host-fungal communication signals. Trends in Microbiol. 15:109-118.

Vick, B.A. 1993. Oxygenated fatty acids of the lipoxygenase pathway. In: Moore, T.S. (ed.), Lipid Metabolism in Plants. CRC Press, Boca Raton, FL, USA, pp. 167-191.

Wasternack, C. 2007. Jasmonates: An update on biosynthesis, signal transduction and action in plant stress response, growth and development. Ann. Bot. 100:681-697.

Weber, H. 2002. Fatty acid-derived signals in plants. Trends in Plant Sci. 7:217-224.

Zieslin, N., Ben-Zaken, R. 1991. Peroxidase, phenylalanine ammonia-lyase and lignification in peduncles of rose flowers. Plant Physiol. Biochem. 29:147-151.

Zoeller, M., Stingl, N., Krischke, M., Fekete, A., Waller, F., Berger, S., Mueller, M. 2012. Lipid profiling of the Arabidopsis hypersensitive response reveals lipid peroxidation and fragmentation processes: Biogenesis of pimelic and azelic acid. Plant Physiol. 160:365-378 